\title{
THE UCP 600 RULES IN LETTER OF CREDIT (LC): SELECTED ISSUES
}

\author{
Rosmawani Che Hasyim, Senior Lecturer, Faculty of Business \& \\ Accountancy, University of Malaya, Malaysia. \\ Email: wanie285@um.edu.my
}

Abstract: The Uniform Customs and Practice (UCP) is the primary source for letter of credit $(L C)$ transaction. Prior to the publication of the UCP, the rules in LC originating from trade customs and practices were not unanimously applied by traders. The International Chamber of Commerce (ICC) whose function is to harmonize the various trade customs practiced in LC, had initiated to compile those rules and published them under one specific reference and named it as the UCP. The UCP is always been updated in order to serve current market needs in regards to LC issues. Thus far, there is no specific statute regulated for LC. The UCP, though customary in nature and has no legal effect, has been adopted by more than 175 countries. Currently, it is unlikely to find the LC transactions, which is not governed by the UCP. Compared to the previous versions, the latest version of the UCP 600 is claimed to be comprehensive and offers modification to the preceding LC rules. This paper discusses the rules provided by the latest UCP 600 focusing on the significant issues in LC such as bankers' autonomy, revocable and irrevocable $L C$, strict compliance, notice of refusal and fraud. Comparisons are scrutinized with the previous versions of the UCP and reviews are highlighted wherever necessary. In addition, reference is sought to case-law to illustrate certain issues. Furthermore, this paper examines the improvements contributed by these latest rules. Last but not least, it seeks to submit proposals for future improvement of the current UCP 600.

Keywords: UCP 600; Letter of Credit; autonomy; strict compliance; notice of refusal, fraud.

\section{INTRODUCTION}

Letter of credit (LC) is claimed to be the most famous and common method of payment in international trade. Due to its characteristics, 
which provides security and facilitate trade between exporter and importer, LC is frequently used and always referred to as a 'life-blood of international trade and commerce. ${ }^{1}$ LC serves as an important tool to overcome the problems of trustworthiness between exporter and importer. The role and function of LC is to provide efficient payment by using the bank as a reliable paymaster to advance payment. The exporter will be automatically paid once he has presented to the bank documents which are strictly complying the LC requirements, whereas the importer does not have to pay should the exporter's documents contain discrepancies and non-compliance with the description of the goods in the underlying sale cotract.

LC transaction is governed by the Uniform Customs and Practice for Documentary Credit (UCP). The UCP contains a compilation of rules, which are originated from ancient traders' practices. Previously, these rules were not formally published. In order to avoid ambiguity and divergent practices, the International Chamber of Commerce (ICC) had taken a reasonable effort to gather those practices and codified them under one reference and published it in a form of rules, named the UCP. The first edition of the UCP was published in UCP 1933; and it has been revised in 1951 (UCP Revised No.151), 1962 (UCP Brochure No. 222), 1974 (ICC Publication No. 290), 1983 (ICC Publication No. 400) and 1993 (ICC Publication No.500). The latest revision is version 600, which is implemented on $1^{\text {st }} \mathrm{July}, 2007$ (ICC Publication No. 600).

\section{PROVISIONS OF UCP 600 - A COMPARISON}

\section{Principle of Autonomy: Article 5}

Principle of autonomy indicates LC is separate from the underlying sale contract. The duty of a bank to make payment is subjected to compliance of exporter's documents. In pursuant to this, the bank shall not involve with any dispute relating to the goods under the sale contract. Furthermore, any conflict between importer and exporter arising out of the sale contract will not be a condition to the bank for dishonour of payment.

Per Kerr J, RD Harbottle (Merchantile) Ltd v National Westminster Bank Ltd [1977] 2 ALL ER 862. 
The UCP 600 enhances the role of the banks in LC transaction, which is restricted to documents. The banks, be it issuing bank, confirming bank or negotiating bank are dealing with documents only and not with goods, services or performance. Prior to this provision, the previous UCP did not specify this position when it is generally stated that 'people' in LC are dealing with documents only. The word 'bank' is not specifically mentioned; rather it is impliedly categorized a bank under 'people'. The use of the word 'people' is criticized as not suitable since in LC transaction, not all people are restricted to deal with documents since exporter and importer are the parties who are also concerned with the goods transacted. ${ }^{2}$ The only party who is dealing with document is the banks. Thus, article 5 is more idyllic in designating the bank's autonomous obligation in regards to LC documents. It obviously separates the bank with the sales contracts entered into by the importer and exporter. Likewise, this provision totally encapsulates the function of the bank relating to the documents only.

\section{All Credits Are Irrevocable - Article 3}

Prior to the UCP 600, LC is categorized into two types, revocable and irrevocable. (Article 6, UCP 500). Revocable credit is a credit that can be cancelled or amended by the applicant without prior notice given to the beneficiary. (Article 8(a), UCP 500). This characteristic reflects that a revocable credit is not absolutely secure as the applicant importer may cancel it at any time without having any responsibility to notify the exporter. ${ }^{3}$ It is noted that a revocable credit may give leeway for a importer who has received a better offer for sale of similar goods to break on his contract with the exporter and terminate the LC. ${ }^{4}$ Consequently, the exporter's position is vulnerable since he has no choice but to seek legal redress, which incurs costs. Even though this kind of LC is not popular due to its lack of security, revocable credit is still relevant, as its issuance cost

International Chamber of Commerce, (2007). ICC Commentary on the UCP 600, Article-by-Article Analysis by the UCP 600 Drafting Group, ICC Services, Publications Department.

3 Per Bailhace J, Cape Asbestos Co Ltd v Lloyd's Bank Ltd, [1921] WN 274, at 275

4 Chuah, J.C.T, (2005). Law of International Trade, $3^{\text {rd }}$ Edition, Sweet \& Maxwell, London. 
is cheaper. Parties who have a good business relationship such as a parent company and its subsidiary have always prefer to use this type of LC. Their purpose of using revocable LC is simply to get payment for the goods and there is no necessity to opt for irrevocable credit.

By virtue of Article 3 of the UCP 600, the above category of a revocable credit has been repealed. Thus, the revocable concept is no longer covered under UCP 600 and it remained with the UCP 500. However, it is interesting to note that despite Article 3 of the UCP 600 , revocable LC can still be issued or allowed to be circularised by virtue of Article 1. Revocable LC is embedded under the meaning of Article 1, which states:

'...they are binding on all parties thereto unless expressly modified or excluded by the credit.'

This article provides some room for business people who wish to opt for revocable LC by modifying or excluding parts of the Articles. Frequent fluctuation of prices in the open market, especially of commodities and other limited supplied goods, may trigger the use of a revocable LC. It would be useful for the importer to insist on the issuance of revocable LC in order to avoid a sudden increase of price in the country of the exporter before shipment has taken place.

Unlike revocable credit, an irrevocable credit gives a binding undertaking to the beneficiary, which cannot be revoked once communicated. ${ }^{5}$ Implicitly, it creates an irrevocable undertaking on the part of the issuing bank to pay the beneficiary as long as the conditions of the LC are complied with. (Article 9(a), UCP 500; Articles 7, 8, UCP 600). Thus, it provides more security to the beneficiary as it cannot be amended or cancelled without the agreement of all the parties to the credit. (Article 9(d), UCP 500; Article 10(a), UCP 600). In a local case of Standard Chartered Bank Malaysia Bhd v Duli Yang Maha Mulia Tuanku Ja'afar Ibni Almarhum Tuanku Abdul Rahman, Yang Di Pertuan Besar Negeri Sembilan Darul Khusus, [2009] 4 MLJ 1, it was held that "an irrevocable Standby Letter of Credit cannot be revoked unilaterally

Richard King, Gutteridge and Megrah's Law of Bankers ' Commercial Credits, $8^{\text {th }}$ Edition, Europa Publications, 2001. 


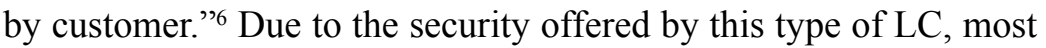
of the LCs issued are irrevocable. The irrevocable LC becomes binding once it is communicated to the beneficiary. ${ }^{7}$ Nevertheless, the UCP 600 does not provide detailed rules relating to the character of irrevocable credit. Thus, due to this loophole in the UCP 600 the rules relating to the irrevocable credit provided by the UCP 500 still can be referred to. For the sake of convenience, it is suggested that the characteristic of the irrevocable credit shall be expressly provided in the next future UCP.

\section{Strict Compliance - Article 14(D), (E), (J), Article 18(C)}

In LC transaction, exporter must present the documents to the bank in order to claim payment for the goods. These documents must be in strict compliance with LC's requirement. Should the exporter's presentation contain discrepancies, the bank will not honour. It is established that the percentage of documentary rejection due to noncompliance on the first presentation by the exporter is amount to $75 \%$. One of the aims of the Working Group Committee in drafting the UCP 600 is to reduce the volume of documentary rejection, which is claimed to be due to the rigidity of the provisions in the previous UCP, ie UCP 500 in regards to documentary compliance. Thus, the UCP 600 is drafted to simplify the requirement of documentary compliance in order to eradicate the problem of non-compliance.

Previously, the UCP 500 through the provision of Article 13(a), emphasized that the documents must be consistent with one another, otherwise, it will be amount to non-compliance. Significantly, by virtue of certain provisions in the UCP 600, this requirement deems to be less strict. ${ }^{8}$ (Christenfield \& W. Melzer, 2007; Younger, 2010). Article 14(d), UCP 600 expressly provides:

6 Per Abdul Hamid J, Standard Chartered Bank Malaysia Bhd v Duli Yang Maha Mulia Tuanku Ja'afar Ibni Almarhum Tuanku Abdul Rahman, Yang Di Pertuan Besar Negeri Sembilan Darul Khusus, [2009] 4 MLJ 1.

7 Jack, Raymond (2001). Documentary Credits: The Law and Practice of Documentary Credits Including Standby Credits and Demand Guarantees, $3^{\text {rd }}$ Edition, Butterworths, London.

8 Alan M. Christenfield \& W. Melzer Shepard, (2007), New Rules for Letters of Credit, New York Law Journal, Thursday, February 1. Younger, Sara, (2010). The Reality of the Strict Rule, DCINSIGHT, Vol. 16 No 1, January-March. 
Data in document, when read in context with the credit, the document itself and international standard banking practice, need not be identical to, but must not conflict with, data in that document, any other stipulated documents or credit."

It denotes that the requirement of compliance is fulfilled if the content of documents is not conflict with each other as well as with LC terms. The above article has softened the requirement of compliance by using the phrase 'need not be identical to, but not conflict,' which impliedly rejected the mirror image or literal approach of the data in documents with the LC terms. Obviously, this modification has lessened the exporter's burden relating to documentary compliance as the requirement for compliance becomes simpler and easier to perform. In addition, it is expected to eliminate conflicts between different documents, which is the most frequent ground for the dishonour of documents presented under commercial LCs. ${ }^{9}$ Furthermore, it gives the bankers a greater degree of flexibility that should result in fewer discrepancies and rejections. ${ }^{10}$

But again, this provision does not objectively state the criteria of compliance. It undoubtedly implies a wider compliance approach, but it opens up room for potential new disputes for example, to what extent the data is not in conflict with each other.

Another practical solution to reduce the volume of discrepancies in documentary presentation is Article 14(e) which allows the goods in all documents (other than the commercial invoice) to be described in general and not be in conflict with LC requirements. ${ }^{11}$ Moreover, Article 14(j) provides that addresses of the beneficiary and applicant need not be the same as those in the credit, provided that they are in the same respective country. This provision is considered as helpful release to the exporter against the problems of inconsistency of the spelling for the same address. Thus, in the new position under the UCP 600 , such non-compliance is no longer considered as discrepancy.

\footnotetext{
9 Carter H. Klien, Letter of Credit Development, (2006)

10 Roberto, Bergami, Will the UCP 600 Provide Solutions to Letter of Credit Transactions? (June, 2007), Vol. 3, No. 2, International Review of Business Research Papers.

11 Todd, Paul, (2003). Maritime Fraud, Informa Professional, London
} 
However, despite the tolerance offered by the UCP 600, it does not promise one hundred per cent leniency for the exporter. ${ }^{12}$ The requirement of strict compliance still remains in Article 18(c) relating to the description of the goods in a commercial invoice. It states:

The description of the goods, services or performance in a commercial invoice must correspond with that appearing in the credit."

The above provision expressly maintains the requirement of strict compliance in commercial invoice. Generally, the leniency offered by the UCP 600 to other LC documents (Article 14 (e), UCP 600) and addresses (Article 14(j), UCP 600) are not extended to commercial invoice since the phrase "must correspond" with the requirement of LC in Article 37(c) of the previous UCP 500 is still maintained. However, by virtue of Article 14(d) above, it could be suggested that the phrase "must correspond" should be construed within the meaning of this provision, which offers less rigidity in documentary compliance.

\section{Notice of Refusal - Article 16}

If exporter's documents contain discrepancies, a bank need not honour and must send a notice of refusal to the exporter or his bank. The previous version of the UCP 500 imposed on the Issuing Bank, the Confirming Bank or the negotiating bank, to observe a reasonable time, not to exceed seven (7) banking days following the day of receipt of the documents, to examine the documents and determine whether to take up or refuse the documents and inform the party from which it received the documents accordingly. The current UCP provisions have simplified the matter. ${ }^{13}$ The UCP 600 introduces a concept of conditional refusal that offers some leniencies and protections for bankers. The emergence of Article 16 of UCP 600 has eased the tension suffered by banks in dealing with discrepant documents, whereby it allows the bank to practice

$12 \quad I d$.

13 Reinhard, Langerich, "An Improved UCP that Has Solved Many Problems", DCINSIGHT, January-March 2007. 
'conditional refusal.' This procedure would make the bank's duty to justify compliance or refusal much easier. The new Article 16 of the UCP 600 has modified the terms of Article 14 of the UCP 500 in dealing with discrepant documents. The bank may refuse to honour the draft under an LC if the presentation of the documents is not compliant. (Article 16(a)). In doing so, the bank must notify the presenter by giving a notice of refusal. The notice must be given by telecommunication or by any expeditious means no later than the close of the fifth banking day following the day of presentation. (Article 16(d), UCP600).

The previous versions of the UCP did not emphasize on the format of a notice of refusal. The UCP 600 requires for a more specific refusal notice to be prepared by the bank upon rejection of noncompliance documents. It is expressly stated in Article 16(c) that there is a duty to provide such notice, in the following wording:

'When a nominated bank acting on its nomination, a confirming bank, if any, or the issuing bank decide to refuse to honour or negotiate, it must give a single notice to the effect to the presenter.'

The above provision continues to list down the following specific formalities and requirements pertaining to the notice, which must be fulfilled by a bank:

a) Comprise a single notice;

b) State that it is one of refusal;

c) State each discrepancy relied upon; and

d) Select one of the four options as to presented documents. ${ }^{14}$

The UCP 600 offers more options to the bank compared to the previous version of the UCP 500 which gave only two choices, either to be held at the disposal of the presenter, or else to returned to presenter. (Art $14 \mathrm{~d}$ (ii), UCP 500). These options were deemed as inadequate and not compatible to the demand of market need. ${ }^{15}$ It should be highlighted that, a single notice in the UCP 600 indicates

\footnotetext{
14 Mohd Hwaidi, The Story of the English Strict Compliance Principle in Letters of Credit and Its Consistency with the UCP, JIBLR, 2014, pp. 1-15.

15 Ibid.
} 
that a bank must avoid from giving multiple notice. ${ }^{16}$ Failure by the bank to observe this requirement will trigger preclusion rule. (Article16(f), UCP 600). Simultaneously, a bank must expressly states that it refuses to negotiate or to honour; otherwise the bank will be precluded from claiming that the documents contain noncompliance.

Furthermore, it should be emphasized that a bank must submit the notice of refusal no later than the close of the fifth banking day following the day of presentation. This express provision in Article 16(d) has been further interpreted by the court of appeal in the case of Fortis Bank SA/NV (2) Stemcor UK Ltd v Indian Overseas Bank [2011] EWCA Civ 58, that the bank, having given a refusal notice, is under an implied obligation to return the documents with a reasonable promptness; failure of which will preclude the bank from relying on the highlighted discrepancies.

Thus, the banks, either issuing bank or confirming bank must be very careful in dealing with discrepant document where they have to follow strictly the requirement of notice of refusal; failing which will trigger preclusion rule.

\section{Fraud in LC}

Fraud is proven to be the most serious problem, which causes disaster to LC transaction. ${ }^{17}$ Thus far, there is no provision of fraud in all versions of the UCP and the matter is left to be dealt by national law. However, in most cases, it is established that national law is not 'comprehensive' and 'strong' enough to deal with commercial matters such as LC, which is purely technical. Consequently, divergent survives since national law varies in its application. There are a lot of fraud cases, which failed to serve a reasonable punishment to the fraudsters since it is obviously difficult to prove the existence of a clear or actual fraud in those

16 Mohd Hwaidi \& Brian Harris, The Mechanics of Refusal in Documentary Letter of Credits: An Analysis of the Procedures introduced by Article 16 UCP 600, JIBLR, 2013, pp. 1-13

17 Davidson, Alan, Fraud, the Prime Exception to the Autonomy Principle in Letters of Credit " [2003] IntTBLawRw 2; (2003) 8 International Trade and Business Law Review 23 
cases where the standard of proof in fraud cases is very high. (Sztejn v J. Henry Schroder Banking Corporation, 177 Misc. 719, 31 NYS 2d 631 (1941); Banco Santander SA v Bayfern Ltd [2000] 1 All ER (Comm) 776, CA; Discount Records Ltd v Barclays Bank Ltd and Barclays Bank International Ltd [1975] 1 All ER 1071; United City Merchants (Investments) Ltd v Royal Bank of Canada [1982] 2 All ER 720). In addition, fraud exception in LC only recognized fraud on documents and not fraud committed on the goods. Due to this condition, fraudsters in most fraud cases were released and fraud crimes continue to spread with the advance of IT and technology system. In relation to this issue, the statement that "principle of autonomy should not be extended to protect the unscrupulous seller" should be reflected by an express provision in the UCP. (Per Shientag J). Thus, fraud provisions, which are broader in scope and clearer in its interpretation, should be included in the next revision of the UCP. For this purpose, the US model of the UCC, Article 5 and PRC Rules for Supreme Court of China, Article 8, which recognised the existence of fraud in the goods as an exception to the principle of autonomy in LC; could be used as guidance to deal with this issue.

\section{CONCLUSION}

Having highlighted the UCP and LC issues in those disputable angles, it should be noted that the UCP is a mere guidelines and the application of the rules in most cases are interpreted by case law. In cases pertaining to documentary compliance, reference to ICC Guidelines on International Standard Banking Practice and the International Chamber of Commerce Expert Opinions will be referred to. The UCP is not static and will continuously be updated to suit the demand of current trade practice. Still, disputes pertaining to LC transactions survive how well the UCP is drafted.

\section{BIBLIOGRAPHY}

Davidson, A. F. The Prime Exception to the Autonomy Principle in Letters of Credit “ [2003] IntTBLawRw 2; (2003) 8 International Trade and Business Law Review 23. 
Alan M. Christenfield. \& W. Melzer Shepard. New Rules for Letters of Credit, New York Law Journal, Thursday, February 1, 2007.

Banco Santander SA v Bayfern Ltd [2000] 1 All ER (Comm) 776, CA.

Carter H. Klien. Letter of Credit Development. (2006).

Chuah, J.C.T, (2005). Law of International Trade, 3rd Edition, Sweet \& Maxwell, London.

Discount Records Ltd v Barclays Bank Ltd and Barclays Bank International Ltd [1975] 1 All ER 1071.

Fortis Bank SA/NV (2) Stemcor UK Ltd v Indian Overseas Bank [2011] EWCA Civ 58.

International Chamber of Commerce. (2007). ICC Commentary on the UCP 600, Article-by-Article Analysis by the UCP 600 Drafting Group, ICC Services, Publications Department.

Intraco Ltd v Notis Shipping Corporation of Liberia: The Bhoja Trade [1981] 2 Lloyd's Rep 256 at 257.

Mohd Hwaidi, \& Brian Harris. The Mechanics of Refusal in Documentary Letter of Credits: An Analysis of the Procedures introduced by Article 16 UCP 600, JIBLR, 2013, pp. 1-13.

Mohd Hwaidi. The Story of the English Strict Compliance Principle in Letters of Credit and Its Consistency with the UCP, JBBLR, 2014, pp. 1-15.

Jack, Raymond. (2001). Documentary Credits: The Law and Practice of Documentary Credits Including Standby Credits and Demand Guarantees, 3rd Edition, Butterworths, London.

Per Bailhace J. Cape Asbestos Co Ltd v Lloyd's Bank Ltd, [1921] WN 274, at 275.

Per Abdul Hamid J. Standard Chartered Bank Malaysia Bhd v Duli Yang Maha Mulia Tuanku Ja'afar Ibni Almarhum Tuanku Abdul Rahman, Yang Di Pertuan Besar Negeri Sembilan Darul Khusus, [2009] 4 MLJ 1.

Per Kerr J. RD Harbottle (Merchantile) Ltd v National Westminster Bank Ltd [1977] 2 ALL ER 862.

RD Harbottle (Merchantile) Ltd v National Westminster Bank Ltd [1977] 2 ALL ER 862, per Kerr J, at 870.

Reinhard, Langerich. "An Improved UCP that Has Solved Many Problems”, DCINSIGHT, January-March 2007. 
Richard King. Gutteridge and Megrah 's Law of Bankers' Commercial Credits, $8^{\text {th }}$ Edition, Europa Publications, 2001.

Roberto Bergami. UCP 600: Letter of Credit Rules Revised.

Roberto, Bergami. Will the UCP 600 Provide Solutions to Letter of Credit Transactions? (June, 2007), Vol. 3, No. 2, International Review of Business Research Papers.

Todd, Paul. (2003). Maritime Fraud, Informa Professional, London Sztejn v J. Henry Schroder Banking Corporation, 177 Misc. 719, 31 NYS $2 d 631$ (1941), per Shientag J.

United City Merchants (Investments) Ltd v Royal Bank of Canada [1982] 2 All ER 720.

Younger, Sara. (2010). The Reality of the Strict Rule, DCINSIGHT, Vol. 16 No 1, January-March 2010. 